\title{
LATIHAN UJI JALAN 6 MENIT TERHADAP KAPASITAS FUNGSIONAL PENDERITA POST TUBERKULOSIS DI PUSKESMAS BATUA RAYA MAKASSAR : LITERATURE REVIEW
}

\author{
Examination of 6 Minutes Walking Test Towards Functional Capacity of Post \\ Tuberculosis Patients in Puskesmas Batua Raya Makassar: Literature Review
}

\author{
Andi Fajriansi' ${ }^{1}$, Kusrini Kadar ${ }^{2}$, Muh. Nasrum \\ ${ }^{1}$ Mahasiswa Keperawatan Fakultas Kedokteran Universitas Hasanuddin, Makassar \\ ${ }^{2}$ Dosen Program Studi Ilmu Keperawatan Universitas Hasanuddin, Makassar \\ ${ }^{3}$ Dosen Program Studi Ilmu Kedokteran Universitas Hasanuddin, Makassar \\ Korespondensi : ansi.hermawan@gmail.com
}

\begin{abstract}
ABSTRAK
Latar Belakang: Data WHO 205 negara tercatat laporan TB dunia kurang lebih 99\% populasi dunia dalam tahap pencegahan, diagnosis dan pengobatan penyakit. Pada tahun 2014 Indonesia menempati urutan ketiga kasus TB terbanyak sebanyak 322.806 kasus dengan angka keberhasilan pengobatan di Indonesia tinggi sebanyak $88 \%$. Tuberkulosis menyerang paru yang menurunkan fungsi pengembangan paru akibat fibrosis paru difus sehingga menurunkan kapasitas fungsional hal ini berlanjut meskipun penderita telah dinyatakan sembuh. Dalam meningkatkan kapasitas fungsional dapat dilakukan dengn uji klinis kemampuan berjalan yaitu dengan cara latihan jalan 6 menit untuk menilai prognosis pasien dalam menjalani kehidupan sehari-hari.

Metode : Dalam pencarian literatur mengidentifikasi artikel 5 tahun terakhir. Kata kunci yang digunakan 6MWT dan Tuberculosis didapatkan 10 artikel yang mendukung. Data base yang digunakan Pubmed, Ebsco dan google elektronik. Kritikal appraisal dilakukan untuk memilih artikel pendukung.

Hasil : Dengan melakukan latihan tes berjalan 6 menit secara intensif maka akan menimbulkan perubahan kapasitas fungsional, cepat atau lambatnya kelelahan seseorang dapat diperkirakan dari kapasitas paru. Kapasitas paru menunjukkan kapasitas maksimal oksigen yang digunakan oleh tubuh (VO2 maks). Semakin banyak oksigen yang diserap oleh tubuh menunjukkan semakin baik kinerja otot dalam bekerja sehingga semakin tinggi VO2maks maka menunjukkan kapasitas fungsional yang prima.

Kesimpulan : Penyakit tuberkulosis yang tidak hanya menimbulkan dampak terhadap perubahan fisik, tetapi juga sosial. Meskipun telah dinyatakan sembuh tapi kapasitas fungsional untuk bisa melakukan aktivitas seharihari mengalami keterbatasan untuk itu diperlukan latihan uji jalan 6menit untuk meningkatkan kapasitas fungsional.
\end{abstract}

Kata kunci : Post tuberkulosis, kapasitas fungsional, latihan uji jalan 6 menit

\begin{abstract}
Background: WHO data on 205 countries recorded a world TB report of approximately 99\% of the world's population in the stage of prevention, diagnosis and treatment of disease. In 2014, Indonesia ranked the third highest number of TB cases with 322,806 cases with a high success rate of treatment in Indonesia of $88 \%$. Tuberculosis attacks the lung which decreases pulmonary developmental function due to diffuse pulmonary fibrosis thereby decreasing functional capacity and this continues even though the patient has been declared cured. In increasing functional capacity, clinical trials on walking ability can be carried out by 6 minutes walking exercise to assess the patient's prognosis in living their daily lives.

Method: In the literature search identified articles in the last 5 years. Keywords used 6MWT and Tuberculosis found 10 articles that support. The data base used is Pubmed, Ebsco and Google Electronics. Critical appraisal is done to select supporting articles.

Results: By conducting an intensive 6-minute walking test it will cause changes in functional capacity, sooner or later someone's fatigue can be estimated from lung capacity. Lung capacity indicates the maximum capacity of oxygen used by the body (VO2 max). The more oxygen absorbed by the body shows the better the performance of muscles in the work so the higher VO2maks it shows the prime functional capacity.

Conclusion: Tuberculosis is not only an impact on physical changes, but also social. Although it has been declared cured, but the functional capacity to be able to carry out daily activities is limited, therefore a 6 minute walk test exercise is needed to increase functional capacity.
\end{abstract}

Keywords: Post tuberculosis, functional capacity, 6 minute walk test exercise 


\section{PENDAHULUAN}

Program tuberkulosis Nasional telah berhasil mencapai target MDGs berupa meningkatkan penemuan kasus baru BTA positif sebanyak $70 \%$ dan angka kesembuhan $85 \%$. Tuberkulosis menyerang paru yang dapat menurunkan fungsi pengembangan paru akibat fibrosis paru difus. Hal tersebut dapat mengakibatkan penderita akan mengalami gangguan pertukaran gas atau dispnea yang progresif sehingga menurunkan kapasitas fungsional. Berbagai prosedur tes fungsional untuk penilaian fungsi cardio-paru dan kapasitas fisik. Banyak dari prosedur diagnostik termasuk evaluasi yang sangat kompleks dari fungsi jantung dan paru tapi membutuhkan peralatan yang mahal dan memakan waktu yang lama seperti spirometri. beberapa tes yang popular dan sederhana seperti tes naik turun tangga, uji jalan 6 menit lebih saring dilakukan. Uji jalan 6 menit merupakan hasil modifikasi dari uji jalan 12 menit sebagai tes untuk menilai fungsional pasien, selain itu juga sebagai refleksi dari aktivitas sehari-hari juga cara yang efektif digunakan dalam evaluasi status fungsional, dan prognosis pasien dengan beragam gangguan fungsi kardiorespirasi. Dari hasil wawancara, petugas penanggungjawab TB menyatakan bahwa meskipun pasien sudah dinyatakan sembuh menurut pemeriksaan medis tapi seringkali pasien masih mengeluh lemes, cepat lelah dan tidak bisa beraktifitas seperti sebelum sakit. Untuk itu perlu ada tindak lanjut kepada penderita TB yang telah diyatakan sembuh untuk mengembalikan kemampuan fungsional pada dirinya sehingga bisa melakukan aktivitas sehari-hari.

Tujuan penelitian ini adalah untuk mendeskripsikan kapasitas fungsional pada post tuberculosis melalui tes uji jalan 6 menit

\section{LANDASAN TEORI}

Tuberkulosis merupakan penyakit menular yang disebabkan oleh bakteri Mycobacterium Tuberculosis yang sebagian besar menyerang paru tapi juga menyerang organ tubuh lainnya (Depkes, 2008). Penyebab dari penyakit ini adalah bakteri Mycobacterium tuberculosis. Bakteri ini dapat bertahan pada kondisi rumah atau lingkungan yang lembab dan gelap sampai berbulan-bulan namun dapat mati apabila terkena sinar matahari (widoyono, 2011). Diagnosis tuberkulosis ditegakkan berdasarkan pemeriksaan gejala klinis, mikrobiologi, radiologi, dan patologi klinik. Pada program tuberkulosis nasional, penemuan BTA melalui pemeriksaan dahak mikrokopis merupakan diagnosis utama. Penderita akan mengalami keadaan yang kurang menguntungkan karena berkurangnya aktivitas yang dapat mempengaruhi sistem musculoskeletal, respirasi, kardiovakular dan lainnya. Penderita akan mengalami penurunan kapasitas fungsional untuk beraktivitas kehidupan seharihari. Pada tahun 1963, Balke mengembangkan tes fungsi cardio-paru yang mudah dilakukan dengan mengukur jarak jalan dalam periode waktu tertentu, tes jalan 12 menit telah dikembangkan untuk mengukur kapasitas fungsional pada individu yang sehat (Cooper, 1968) tapi tes ini tidak bisa dilakukan pada penderita penyakit pernapasan karena durasi dan ketegangan fisik selanjutnya tes jalan 6 menit dikembangkan (Butland, RJA., Pang, J., Gross ER., Geddes, DM.,1982) karena lebih mirip dengan aktivitas fisik dalam kehidupan sehari-hari, lebih mudah untuk dilakukan, lebih ditoleransi dan mewakili fungsi paru-paru. Selain itu uji jalan 6 menit sebagai prediksi morbiditas dan mortalitas pada subyek dengan penyakit paru obstruktif kronis (Solway, Brooks, Lacasse, \& Thomas, 2001). Tes jalan 6 menit dilakukan sesuai dengan pedoman American Thoracic society (ATS statement: Guidelines for the six-minute walk test), tes sederhana dan praktis ini hanya membutuhkan panjang lintasan 30 meter pada permukaan yang datar dan ditempuh jangka waktu 6 menit dalam satu siklus latihan tes dilakukan 2 kali (T1 dan T2) dengan nilai jarak tempuh tertinggi dijadikan hasil pengukuran (baseline). Tes ini menilai tingkat submaksimal kapasitas fungsional sehingga memberikan informasi kemampuan pasien untuk melakukan kegiatan sehari-hari melalui peningkatan fungsi paru, fungsi jantung, kekuatan otot, fungsi kognitif. (ATS, 2002).

\section{METODELOGI PENELITIAN}

Desain penelitian adalah model atau metode yang digunakan peneliti untuk melakukan suatu penelitian yang memberikan arah terhadap jalannya penelitian (Dharma, 2011). Penelitian ini merupakan jenis penelitian non eksperimen dengan pendekatan deskriptif kuantitatif, dimana penelitian ini menggambarkan data kuantitatif kapasitas fungsional sesuai dengan hasil tes jalan 6 menit. Tehnik sampling yang digunakan adalah Nonprobability sampling, yaitu purposive sampling dimana sampel 
dipilih berdasarkan pertimbangan sesuai dengan kebutuhan penelitian dalam hal ini memenuhi kriteria inklusi yang telah ditetapkan oleh peneliti dengan kriteria usia minimal 19 tahun, tidak mengalami penyakit jantung dan kelemahan ekstremitas, tidak memiliki riwayat operasi abdomen 6 bulan terkahir, hasil pemeriksaan tekanan darah 180/120 mmHg.

\section{KESIMPULAN DAN SARAN}

Berdasarkan landasan teori dan penelitian sebelumnya bahwa post tuberkulosis mengalami perubahan kapasitas fungsional sehingga ada penurunan kemampuan untuk berkativitas sehari-hari dan latihan jalan 6 menit salah satu upaya untuk mengembalikan kapasitas fungsional yang optimal. Dan sebagai saran cakupan wilayah penelitian diperluas sehingga lebih banyak responden yang didapat sehingga hasilnya lebih akurat.

\section{DAFTAR PUSTAKA}

Abidin, A. Y., Yunus, F., Wiyono, W.H., Ratnawati, A. (2009). Manfaat Rehabilitasi Paru Dalam Meningkatkan atau Mempertahankan Kapasitas Fungsional dan Kualitas Hidup Pasien Penyakit paru obstruktif Kronik di RSUP Persahabatan. Jurnal Respirologi Indonesia. Jakarta: Rumah Sakit Persahabatan

American Thoracic Society, ATS Statement Guidelines For The Six-Minute Walk Test. (2002). Am J Respir Crit Care med, 166, 111-117. doi: 10.1164/rccm. $166 / 1 / 111$

Burns, G., Grove. SK. (2011). Understanding Nursing Research Building An Evidence-Based Practice $5^{\text {th }}$ edition. USA; Elsevier

Butland, RJA., Pang, J., Gross ER., Geddes, DM. (1982). Two- six- and 12-Minute Walking Test In Respiratory Disease. BMJ , 284, 1607-1608

Cooper, KH. (1968). A mean of assesing maximal oxygen intake. Correlation between field and treadmill testing. JAMA, 203, 201

Darma. (2011). metodologi penelitian keperawatan panduan melaksanakan dan menerapkan hasil penelitian. Jakarta: Trans InfoMedika

Darmanto. (2007). Respirologi. Jakarta: penerbit buku kedokteran jakarta

Departemen Kesehatan RI. (2008). Pedoman Nasional Penanggulangan Tuberkulosis edisi 2. Jakarta

Departemen Kesehatan RI. (2011). Pedoman Nasional Penanggulangan Tuberkulosis. Jakarta

Nursalam. (2013). Konsep Penerapan metode penelitian ilmu keperawatan. jakarta: salemba medika

Somantri, I. (2007). Asuhan Keperawatan pada pasien dengan gangguan pernapasan. Jakarta: salemba medika

Sugiyono. (2014). Metode Penelitian Kuantitatif, Kualitatif dan R\&D. Bandung: erlangga

Sugiyono.(2016). Metode Penelitian Kuantitatif, Kualitatif dan R\&D. Bandung: CV Alfabeta

widagdo. (2011). Masalah dan tatalaksana penyakit infeksi pada anak. Jakarta: sagung seto

Widoyono. (2011). Penyakit Tropis (Epidemilogi, Penularan, Pencegahan \& Pemberantasannya) edisi kedua. Jakarta: Erlangga

William, DM., Frank, IK., Victor, LK. (2007). Exercise Physiology: Energy, Nutrition, and Human Performance. $6^{\text {th }}$ ed. Baltimore, MD: Lippincot William \& Wilkins : 203,1062

World Health Organization. (2015). The End Tuberculosis Strategy: Global strategy and targets for tuberculosis prevention, care and control after 2015.

Wong,PF et al.(2018). Correlation between 6min walk test and cardiopulmonary exercise test in chines patients, 2,32. doi: 10.4103/prcm.prcm_24_17 